\title{
Religion and Spirituality: the Perspective of Health Professionals ${ }^{1}$
}

\author{
Joelma Ana Espíndula ${ }^{2}$ \\ Elizabeth Ranier Martins Do Valle ${ }^{3}$ \\ Angela Ales Bello $0^{4}$
}

This study examined how health professionals signify the religiosity and faith of patients under cancer treatment and how they themselves experience such phenomena. This is a qualitative-descriptive study, using the phenomenological framework as set out by Stein and Ales Bello, as a way of understanding the human being in its totality - physical, mental and spiritual. Most professionals report they are spiritualists, two are Catholics, one physician is a Buddhist and another is a Spiritist. They believe that religion is inherent to all human beings. Professionals convicted of their religion (less than half) believe in divine protection and recognize religiosity as a support and comfort for patients and their families in coping with illness. They expect patients to live their faith with prudence, never losing sight of reality.

Descriptors: Neoplasms; Religion; Spirituality; Health Professional.

\footnotetext{
${ }^{1}$ Article extracted from Doctoral Dissertation "O significado da religiosidade para pacientes com câncer e para profissionais de saúde", presented to Escola de Enfermagem de Ribeirão Preto, Universidade de São Paulo, SP, Brazil. Supported by Fundação de Amparo à Pesquisa do Estado de São Paulo, process \# 05/53574-8, and of the Coordenação de Aperfeiçoamento de Pessoal de Nível Superior, process \# 0670/07-3.

2 Psychologist, Ph.D. in Sciences. E-mail: espindulajoelma@yahoo.com.br.

${ }^{3}$ Psychologist, Free Lecture, Escola de Enfermagem de Ribeirão Preto, Universidade de São Paulo, WHO Collaborating Centre for Nursing Research Development, SP, Brazil. E-mail: bethvale@eerp.usp.br.

${ }^{4}$ Philosopher, Professor, Universidade Pontifícia Lateranense de Roma, Italy. E-mail: alesbello@tiscali.it.
}

Corresponding Author: Joelma Ana Espíndula Rua Gentil Dias da Silva, 284 B Bairro Nossa Senhora das Graças CEP: 35060-190 Governador Valadares, MG, Brasil E-mail: espindulajoelma@yahoo.com.br 


\section{Religião e espiritualidade: um olhar de profissionais de saúde}

O estudo teve por objetivos compreender como profissionais de saúde significam religiosidade e fé dos pacientes em tratamento de câncer, e como experienciam esse fenômeno. Trata-se de pesquisa qualitativa-descritiva, sob o referencial de análise fenomenológica em Stein e Ales Bello, um modo de compreender o ser humano na sua totalidade - física, psíquica e espiritual. A maioria dos profissionais de saúde se diz espiritualista, dois são católicos, um médico se diz budista e uma médica espírita. Acreditam que a religião é inerente a todo ser humano. Os convictos de suas religiões creem na proteção divina e reconhecem a religiosidade como sustento e conforto para o paciente e seus familiares enfrentarem a situação de adoecimento. Eles esperam que esses enfermos vivam a sua fé com prudência e sempre aderindo à realidade.

Descritores: Neoplasias; Religião; Espiritualidade; Pessoal de Saúde.

\section{Religión y espiritualidad: una perspectiva de profesionales de la salud}

Este estudio tuvo por objetivo comprender como los profesionales de la salud le dan significado a la religiosidad y a la fe de los pacientes en tratamiento de cáncer, y como ellos experimentan ese fenómeno. Se refiere a una investigación cualitativa-descriptiva, bajo el referencial del análisis fenomenológico de Stein y Ales Bello, un modo de comprender al ser humano en su totalidad - física, psíquica y espiritual. La mayoría de los profesionales de la salud se declaró Espiritualista, dos son Católicos, un médico se dice Budista y una médica Espírita. Creen que la religión es inherente a todo ser humano. Los convictos de sus religiones creen en la protección divina y reconocen la religiosidad como sustento y confort para el paciente y sus familiares, también para que puedan enfrentar la situación de enfermarse. Ellos esperan que esos enfermos vivan su fe con prudencia y siempre adhiriendo a la realidad.

Descriptores: Neoplasias; Religión; Espiritualidad; Personal de Salud.

\section{Introduction}

Working with cancer patients is always a challenge due to the complexity of the situation. It requires different professionals jointly working with the patient and, when necessary, the family. It is known that the disease, which poses a threat to life, strikes and affects each involved person not only in his/her bio/psycho/social totality, but also equally in the spiritual sphere. Hence, care delivery should include two dimensions: affective-emotional, and psychosocialspiritual dimensions of patients and caregivers (family members and health professionals).

This study presents, in light of Stein's anthropological philosophy(1-2), a way to understand how health professionals (dentists, physicians, resident physicians, nurses, nursing auxiliaries and psychologists) perceive the religiosity and spirituality of their patients under cancer treatment and how these professionals experience their own spirituality. Studies addressing psycho-oncological subjects, religiosity and spirituality have grown in Brazil and in the world.

A qualitative-descriptive study carried out through bibliographic research, addressing issues concerning death in a bioethical evaluation done by health professionals. It presents as essential that health professionals overcome difficulties inherent to the physician/patient relationship based on a "technological temptation", that is, the temptation to view patient by their parts. One should reunite the fragments and re-compose individuals, frequently already damaged, and establish a commitment to life, understood as the greater good of beings and that is worthy of respect. Foundational issues concerning life and death such as "To what point do we prolong life?" or "What is the objective of medicine: care for physiological indexes or people?" and "What about when the treatment causes 
more suffering than benefit?" are presented to health professionals (especially physicians) who did not receive ready answers from their academic education; these are issues related to the human condition, its finitude, transience and uncertainty(3).

Even if a cure is not obtained, palliative care can give quality to the patient's remaining time of life. It is important to keep in mind that the definition of palliative care according to the World Health Organization includes, in addition to the bio-psychosocial dimension, the spiritual dimension. According to studies and reports, practical recommendations are improved with the joint implementation of spiritual care with palliative care. For many, the spirituality issue occurs in the context of an explicit religious tradition; for others, it may be like a game of philosophical principles or meaningful experiences $^{(4-5)}$.

An important study investigating the influence of spirituality in health was carried out with 464 undergraduate students (from the medical and law programs) in Pelotas, RS, Brazil. A scale addressing spiritual wellness was applied by psychologists or psychology students, taking into account that spiritual well-being is currently considered a protection factor in avoiding minor psychiatric disorders in future professionals. The results revealed that $80 \%$ of the students reported to have a religious or spiritual belief and $86.5 \%$ of these reported one or more spiritual activities such as: praying, meditation, or reading religious texts (Christianity, Judaism, and Islamism). These law and medical students were followers of monotheistic, prophetic, and spiritist religions. The study's contribution, according to the authors, was to promote mental health and encourage future professionals to practice spiritual activities, which can psycho-dynamically influence positive feelings such as self-esteem, and psychosocial and spiritual aspects. Experiencing a positive philosophy of life enables individuals to have a greater awareness and responsibility of things they are supposed to do, not eliminating conflicts that may arise. At the same time, if one does not seek to solve such conflicts, one does not meet desires, needs and requirements one may have deep inside(6).

Another study conducted with psychologists caring for cancer patients identified the meaning these individuals hold of religious faith through semi-structured interviews. Some psychologists revealed in their reports that they cannot talk about religion during therapy sessions because they do not believe that religious faith is the best path through which one can achieve feelings of comfort and wellness. On the other hand, other psychologists valued religious faith, which was part of their routine and which was termed by the author as the "transforming energy, hope". The study concluded that half of the psychologists believe that having faith is the best resource to help someone to cope with an illness and that it is possible to accommodate both science and psycho-spiritual aspects. Some oncologic services already acknowledge the need for having, in addition to a psychologist, a chaplain as a member of the team, regardless of religious order. One qualitative study was carried out with five chaplains (two Catholics, two pastors and one rabbi) to identify the meaning of religious faith in their work with elderly patients with cancer and how they saw the religious faith of their patients. Semi-structured interviews were held with these chaplains and the first results indicate their patients were supported on faith and this becomes the answer to all circumstances and moments of life, directing its meaning(7).

A particular care delivery method was systematically used with terminal patients and became a model for other professionals in the health field. Each of seven health professionals - two nurses, one physician, three psychologists and one volunteer - cared for two terminal patients in 2004 at a hospital and followed the development stages of a psychotherapy intervention. The study aimed to apply and evaluate a training program for health professionals using therapeutic interventions for terminal patients "relaxation, mental images and spirituality" (RIME), re-signifying these patients' spiritual pain. The results of this quantitative and qualitative study indicated that professionals felt well using this new technique. The health professionals showed improved coping skills in their personal grief and psycho-spiritual growth, both professionally and personally. Relevant information is that this technique (RIME) is directed to patients who believe in life after death ${ }^{(8-9)}$.

The conclusion is that studies show the need for health professionals to be attentive to their patients religious faith; they need to acknowledge their spiritual dimension as it brings them stimulus, courage and hope to cope with the disease. Studies also indicate the need to have a psychologist and a chaplain prepared to listen to patients and be spiritually in line (transcendent) with them. This posture can help patients to construct meaning in experiencing suffering inherent to the disease, which in turn could facilitate the care practice of health professionals.

This is an original study in the health field, specifically in oncology, addressing religiosity and spirituality 
grounded on Stein's analysis(10) in the interpretation of Ales Bello in Brazil and in the world. There are no studies addressing this subject in the health field enabling a new perspective on the reality of oncology care.

The phenomenological method was chosen to answer the questions from which this study originated, which was considered appropriate for reflection on how health professionals perceive their patients' spirituality and identify these professionals' experiences in relation to religiosity and spirituality.

This study is expected to inspire health professionals and professors in the field to enable their students to develop humane care and prepare them to deal with the patient-team-family triad.

\section{Method}

Stein's theoretical-methodological framework ${ }^{(10)}$, according to Ales Bello, emphasizes subjective and intersubjective aspects, highlighting the person's uniqueness, seeking to intensify scientific focus, which is essential in this case because it involves health professionals. The phenomenological method is an appropriate resource to access experiences (perception, memory, reflection, decision) and enables one to broaden understanding of the experienced phenomenon. It focuses on experiences and grasps the meaning attributed by an individual to such experiences. This study is directed to the individuals' perceptions concerning what is under study: how health professionals perceive their patients' religiosity and spirituality and how they experience their own religiosity and spirituality ${ }^{(11)}$.

A person is considered to be a bodily, spiritual and emotional being and in this unit, the dimensions are externally independent and internally they complete themselves in an organism that is organized and subordinate to its biological nature. Concluding, the human soul is the center of a being that has a tridimensional nature: spiritual, psychological and physical. The human being is not only a psychophysical being, he/she is also spiritual. This is the essential point and it is through this dimension that other components of the individual are manifested, because the soul (or psyche) has only one core. One can say that the trilogy of a person (spiritual, psychological, and physical) is predisposed to this development process because a person can only become something that is already present in his/her personal being. When a person experiences the outward world, s/ he is influenced and formed by the cultural environment into which $s /$ he is inserted, with a possibility to change the direction of this forming environment ${ }^{(12)}$.
When an individual is before a thing or a person, external and internal reactions occur, which can become feelings, desires and intentions. A simple experiment, experienced by all, is to have an object before them: for example, a glass of water, what do I perceive? A set of sensations. By experiencing something inside oneself (glass), a person perceives her/himself (erlebnis) before that object, which can enable the researcher to identify structures on the subject who makes the experiment and captures the characteristics of this particular object that is outside of him/her (individual)(13). What has been said refers to the concept of conscious experience, and you can observe it applied to sciences (Psychology, Nursing, Nutrition, Medicine, Social Work, Occupational Therapy, among others).

The phenomenological attitude departs from the experience between researcher and subject. The structural analysis of the individual's experience enables understanding existential horizons where experience can be developed. Phenomenological analysis relies on the meaning of life experiences to get to the essence of these experiences, as a description that does not stop at the facts, but which wants to know immediately and intuitively this essential information (of experiences) in a stage which the phenomenological method calls eidetic reduction. It is through transcendental reduction that the researcher subjectively intuits the life experience of the study's subject, and makes his/her reflections. This reflective process is compared to an excavation; it is initially done at a conscious level, through perception and memory, and also at a passive level (that which had been previously grasped), which can be object of an "excavation"(14).

From this perspective of soul, the psyche is structurally grasped as a united psyche altered by spirit. This dimension (spirit) is identified as an activity of the self that updates the abilities of turning to inward objects, composed of the person's experiences, which involves understanding, elaboration of meanings and free positioning of the self in the face of these experiences or external objects of the cultural or natural world. The psyche's experiences are simultaneously influenced by spiritual life, which captures the meaning grasped by corporeity, vital condition (health or disease), by the intensity of sensitive vital forces (how one perceive things, the potential with which one shares experiences with other people, actualizing them or not) and the person's tension (he/she who grasps objects and voluntarily positions her/himself before them). The expression of empathy or intropathy is frequently used 
when one puts him/herself in the other's life experiences, that is, lives another person's experience and does not distinguish between the structure and content of experiences. From this perspective, one determines that the empathic act is a possibility of acknowledging the experience shared by people without asking how the other feels. One is able to grasp how the other feels without saying anything because of the human being's universal structure. However, the content of what is the experience is individual (it belongs to each one's world). Hence, the feeling of another does not belong to the other. For instance, when we recall the reports of these health professionals, we recover something that does not belong to us, and consequently we transcend and seek to understand them within their life-world in that circumstance(15). $^{(15}$.

\section{Participants}

This study's inclusion criterion was being a professional from the cancer team working at CEON, the specialized cancer center of the Beneficência Portuguesa Hospital in Ribeirão Preto, SP, Brazil. A total of 11 interviews were carried out with these professionals (three physicians, four resident physicians, one nurse, one nursing auxiliary, one dentist and one psychooncologist). The researcher sought to schedule times that were most convenient to the professionals and because of their many activities and lack of availability, sometimes the meetings had to be re-scheduled. Most of the interviews were held in the professionals' offices, only one nurse and one nursing auxiliary were interviewed in one of the rooms available for medical consultations.

\section{Procedure}

The study was submitted to and approved by the Research Ethics Committee at the University of São Paulo at Ribeirão Preto, College of Nursing, and data collection was initiated only after approval was obtained.

The researcher approached the health professionals in their workplace, asked them to sign a free and informed consent form, and explained the study's objectives and procedures, ensuring their confidentiality through the adoption of fictitious names. The researcher initiated the interview with the following questions: How do you perceive the cancer patients' religiosity and faith? How do you view faith in your life? The participants could speak freely and, when necessary and relevant for the study, other questions were asked during their reports in order to enlarge and deepen their responses.
The interviews were recorded with a digital recorder. After each interview, the reports were transcribed verbatim. All the invited individuals voluntarily consented to participate in the study.

The number of interviews was not established a priori in order to obtain a comprehensive analysis. Interviews cease when the researcher perceives a convergence of themes - common reports among interviews, which indicates that the essence of experience is being captured. Given the object of study, divergences were also considered.

\section{Results and discussion}

Based on the analysis of Edith Stein's thought, we deemed it important to deepen knowledge and understanding of how health professionals (dentist, physicians, resident physicians, nurses, nursing auxiliary, psychologist) view the religious and spiritual experiences of their cancer patients ${ }^{(15)}$.

The structural elements of the human person (body, psychology, spirit), which are interwoven into a single unit of consciousness, is described, which impedes the researcher from omitting her attention to materiality, from emphasizing the psychological or devaluating the other's rationale and freedom. Hence, the study's subjects are analyzed in their structural and essential constitution as a person. In an interpretative effort of this anthropological philosophy, as a "tool" used to understand the person's structures (health professionals) three three-dimension moments are described, which are sometimes together to better understand its unity, but they can be simultaneously "activated" in each experienced moment.

The core meaning (typology) emerges from Stein's structural and essential analysis - The professionals signify the faith and religiosity of patients with cancer.

\section{The professionals signify the faith and religiosity of patients with cancer}

The health professionals express their opinion on religion, dogmas and beliefs. One dentist said: I believe in this divine protection, but I don't renounce the protection of the glove. Whenever a patient leaves, I clean the chair and material used. I try to relate with the person who is there, not the AIDS or cancer patient... I care for them with neatness, from one to the other (Maria, dentist). Maria seems to provide not only scientific care (technical) to her patients, but also affective care, helping them to reflect, evaluate and make a truthful judgment of their situation, which may be difficult when they use only their perspective. 
Health professionals become aware of their own experience in its corporeity when they experience the perception of another, who is similar to them, as an alter ego, someone with a human structure similar to theirs. Inside this structure, there is a being that needs to position itself in the world. The act of perception is attached to the specific act of empathy. This operation is prior to reflection and elaboration of experience. Empathy is to grasp the other as being a "self" like the subject him/herself, who captures an alter ego that encapsulates the other in his/her inter-subjectivity ${ }^{(16)}$.

In this context, health professionals talk about how they see their cancer patients' faith in God or a Superior Being. The following is a relevant excerpt of a nurse's report: most of the patients say they'd prayed to Our Lady of Aparecida. They show much faith in Our Lady... that they were healed not only by faith... but patients also say they'd accept the treatment (Sueli, head nurse). The nurse reveals that when she feels internally motivated in the relationship with the patient, in a loving and attentive attitude, she goes beyond a physical concern of how the patient is responding to the disease and treatment. She also cares for affective-emotional, and psychosocial and spiritual aspects.

Yet, another professional asks: "what is compassion?" In his words: the meaning is to share the life of Christ (...) isn't life a Calvary? When one shares this passion with another, one is trying to alleviate this Calvary so that it is not so heavy... Instead of only Christ carrying the cross...it'd be less heavy... (João, radiotherapist). He asserts that personal faith helps one to bear and share the suffering journey with another.

Some health professionals question whether Something acts and changes the attitudes and behavior of patients when they want to. They say that this Something - faith and miracles - has not been acknowledged by science yet. What is it you name religion? Religion is an experience of connection with a Superior being. I guess it's inherent to the human being. Now, whether it is Catholicism, Protestantism, Pentecostalism, that expectation that may interfere in the process here (treatment)... I believe there is a Superior Being that guides life (Paulo, Head of the Oncology unit). None of the health professionals can be considered atheist. The religious experience of each of them varies according to the way they grasp the meaning of life and death, disease and health. Some of them are not followers of any religion. Some say they are spiritualists but believe that religion is inherent human beings. They believe in human values and bring their "personal religious" experience into their work.
They seem to "believe" in the Church's miracles through a "process" in which people manage to change their way of seeing things, re-checking their concepts and behavior. Religiosity can be personally experienced but it seems spirituality is not possible if not inserted into a community, in a relationship with another, because life cannot be practiced by itself.

Health professionals in general signify how they perceive the role of religion and spirituality in the life of cancer patients. A physician said: I know that patients have it (faith in God) as a lifeline. This is the way they have to do everything they can, because you know that the treatment has limitations. I don't have any "magic gift" to treat a disease... I have faith in the human being...(Rafael, oncologist). Rafael tries to look at the patient's human values, at the singularity of each person, who has a name, surname, and a life history. A statement of a nurse: There're some patients who are pretty rigid... they don't look when I'm puncturing. They don't even look at the TV, or even blink. They put their hand over their faces to impede their eyes from looking at the TV. They rigorously follow what the church instructs them to do... Some even abandon the treatment and believe they are healed (Sueli, head nurse). She describes some patients as being influenced by the discourse of the pastors of the churches they attend. The patients believe they will be healed only by praying, that they do not need to follow the cancer treatment.

When there is no opportunity to establish bonds, the health professionals complain of a lack of cooperation with and adherence to the recommendations required for the success of the treatment on the part of patients. In addition, professionals manifest sorrow and seem to be frustrated in their roles.

Life is an endless mystery, each individual is much more than his/her own limit, has a "personal core" that can always be developed and grow. From this perspective, the individual perceives his/her demand of being and positions him/herself in the world because he/ she has a vital force. It is through this force that each one positions and situates him/herself in life circumstances. However, this force is not only spiritual, or psychological, or only biological. The force of an individual is a unity, between the dimensions of the spirit and the natural dimensions $^{(17)}$.

The health professionals report their religious experiences. A report of a dentist said: my life is moved by faith...my relationships... things I do... I feel it's a mature faith... I used to believe that one needed to achieve it to have faith; today, I donate myself without expecting anything back. Seeing that patients are well and being able to contribute with my work, it makes me feel gratified. (Maria, dentist). She expresses her 
experience with emotion and a passion for practicing her profession with religious faith with patients and other professionals. Sueli also says: there're times that I could not bear if I were by myself. I know the Lord is with me, He helps me a lot... I know that something is guiding my actions... (Sueli, head nurse). She beliefs in divine protection. She seeks protection and support for her actions in God's word. She routinely prays in her own work to be strengthened by God and by Our Lady of Aparecida and to be guided in life with faith and protection from Them.

Maria (dentist) and Sueli (nurse) experience religion as a more humane and truthful dimension of themselves. They report the experience of faith and comfort in their work. They conceive their experiences as a spiritually intense moment and one of personal growth. They can also be examples of workers because they demonstrate that they live it with love, when they become closer to patients and entirely devote themselves in the relationships they have with patients and the team members. Hence, they show how they manage to overcome their daily routine in the oncologic unit with joy and hope showing on their faces.

For one to have a religious experience, it needs to be based on one's own experience. One can never detach him/herself from his/her religious conditioning and experienced culture. The essential characteristic of Christianity is love. Therefore, when one perceives the potency in a specific figure, one believes in the incarnation of God in human form, that is, present on earth as a human figure. "God is essentially will; He comes down and guides salvation in Himself". It seems that the human being seeks to live the religious sense of something - the deepest and broadest sense one can find in life. And this last sense is religious. The religious being seeks superior powers (absolute powers) to understand and govern his/her life. The human being is aware of his/er finite in time and space, hence, seeks for Something that goes beyond(18).

In general, health professionals signify the importance of spiritual and religious support for cancer patients and their families, but these experiences need to be seen as support, protection and with prudence, not losing sight of reality.

\section{Final considerations}

Most of the team had a naturalistic and practical way of seeing things, and this seems to be an influence of the scientific thought that predominate professionals' mentality in our culture. In the post-modern era, with biotechnology, molecular biology, the discovery of so many new pharmaceutical products to cure diseases, the advancements in the field of medication, the human dimension is being lost. We need to take this issue into account seriously and the first thing to consider when working with human beings is: who is this human being one wants to study? There are many views of the human being and of the world. We should know what conception each professional holds and what consequences it generates.

It seems essential that all the members of a team work in line with the same philosophy and goal. Each needs to share with the group the possibilities of decisionmaking, always based on the idea of what is best for patients when they ask for help and support. From this perspective, professionals need, from the time of their professional education, to learn to look at patients and listen to the other they have inside. One should consider that each patient is unique and ask oneself: what is the best conduct for this patient at this moment?

Health professionals should be a means to help patients to recover the sense of their lives, even with a severe disease, such as cancer. How can one do this? Helping the patient to perceive and know him/herself in the process. In addition, the multi-professional team needs to support, and provide comfort and hope for patients and families, even if a cure is not obtained. No human being lives in the world without having some hope in life.

We expect that all health professionals (psychologists, physicians, nutritionists, physical therapist, chaplains, nurses and nursing auxiliaries, among others) ask themselves whether they have, themselves, the right to seek support from a religion, and from other communities, to better cope with a disease in themselves and in others, to have the possibility of having a "gentle" and dignified death.

\section{References}

1. Ales Bello A. Culturas e religiões: uma leitura fenomenológica. Bauru (SP): EDUSC; 1998.

2. Ales Bello A. Introdução à fenomenologia. Bauru (SP): EDUSC; 2006.
3. Espíndula JA, Pontes AC, Valle ERM, Santos M.A. Bioética e profissionais de saúde: algumas reflexões. Bioethikos. 2007;1(1):68-75. 
4. Paloutzian R, Ellison C. Loneliness, spiritual, well-being and the quality of life. In: Peplau D, Perlman D, organizadores. Loleniness: a sourcebook of current theory. New York: John Wiley; 1982. p. 224-35.

5. Puchalski MDC, Ferrell F, Virani R, Otis-Green S, Baird $P$, Handzo G. Improving the Quality of Spiritual Care as a Dimension of Palliative Care: the report of the consensus conference. J Pall Med. 2009;12(10):885-904.

6. Volcan SMA, Sousa PLR, Mari JDJ, Horta BL. Relação entre bem-estar espiritual e transtornos psiquiátricos menores: estudo transversal. Rev Saúde Pública. 2003;37(4):440-5.

7. Teixeira JJV, Lefèvre F. Humanização nos cuidados de saúde e a importância da espiritualidade: o discurso do sujeito coletivo psicólogo. Mundo Saúde. 2003;27(3):362-8.

8. Elias ACA, Giglio JS. A questão da espiritualidade na realidade hospitalar: o psicólogo e a dimensão espiritual do paciente. Estud Psicol. 2001;18(3):23-32.

9. Elias ACA, Giglio JS, Pimenta CAM. Analysis of the nature of spiritual pain in terminal patients and the resignification process through the relaxation, mental images and spiritualy (RIME) intervention. Rev. Latino-Am. Enfermagem. 2008;6(6):959-65. 10. Stein E. Psicologia e scienza dello spirito: contributi per una fondazione filosófica. 2a ed. Roma: Città Nuova; 1999.
11. Stein E. La struttura della persona humana. Roma: Città Nuova; 2000.

12. Mahfoud M. Centro pessoal e núcleo comunitário, segundo Edith Stein: indicações para estudos sobre família. In: Carvalho AMA, Moreira LVC. Família, subjetividade, vínculos. São Paulo: Paulinas; 2007.

13. Ales Bello A. Fenomenologia e ciências humanas: psicologia, história e religião. Bauru (SP): EDUSC; 2004.

14. Ghigi N. I gradi della costituizione dell' essere nel percorso filosofico di Edith Stein. In: Shahid. M; Alfieri F. Il percorso intellettuale di Edith Stein. Bari: Giuseppe Laterza; 2009.

15. Ales Bello A. Il percorso umano e intellettuale di Edith Stein. In: Shahid M, Alfieri F. Il percorso intellettuale di Edith Stein. Bari: Giuseppe Laterza; 2009.

16. Stein E. Il problema dell' empatia. Roma: Città Nuova; 2000.

17.Ales Bello A. Família e Intersubjetividade. In: Carvalho AMA, Moreira, LVC. Família, subjetividade, vínculos. São Paulo: Paulinas; 2007.

18. Van der Leeuw G. Fenomenologia della religione. Torino: Boringhieri; 1992. 